\title{
Chirality and Fragrance Chemistry: the Stereoisomers of the Commercial Chiral Odorants Muguesia ${ }^{\circledR}$ and Pamplefleur ${ }^{\circledR}$
}

\author{
Agnese Abate, Elisabetta Brenna, "Claudio Fuganti, Francesco G. Gatti, Tommaso Giovenzana, \\ Luciana Malpezzi and Stefano Serra
}

\section{List of contents}

General experimental methods

page $\mathrm{S} 3$

Preparations and spectral data of:

(2RS,3RS)- and (2RS,3SR)-3-Hydroxy-2-methyl-1-phenylbutan-1-one (3)

page S4

(2R,3R)-3-Methyl-4-phenyl-2-butanol ((2R,3R)-syn-1)

page S4

(2S,3R)-3-Methyl-4-phenyl-2-butanol ((2S,3R)-anti-1)

page S4

(2R,3S)-2-Methyl-4-phenyl-2-butanol ((2R,3S)-anti-1)

page S5

(3R)-(-)-3-Methyl-4-phenyl-2-butanone $((R)-8)$

page S5

(S)-2-Phenylpropanol ((S)-11)

page S5

(R)-1-Bromo-2-phenylpropane $((R)-13)$ and $(S)$-1-Bromo-2-phenylpropane $((S)-13)$

page S5

(2RS,4R)-2-Methyl-4-phenylpentanoic acid ((2RS,4R)-14)

page S6

(2RS,4S)-2-Methyl-4-phenylpentanol ((2RS,4S)-2)

page S6

$(2 R S, 4 R)$-2-Methyl-4-phenylpentanol $((2 R S, 4 R)-2)$

page S6

2S,4R)-2-Methyl-4-phenylpentanol ((2S,4R)-2) and (2R,4R) - Acetic acid 2-Methyl-4-phenylpent-1-yl ester $((2 R, 4 R)-15)$.

page S6

$(2 R, 4 R)$-2-Methyl-4-phenylpentanol $((2 R, 4 R)-2)$

page S7 
General experimental methods: Lipase PS Burkholderia cepacia (Amano Pharmaceuticals Co., Japan) and Porcine pancreatic lipase (Sigma) were employed in this work. GC-MS analyses were performed on a HP 6890 gas-chromatograph equipped with a 5973 mass-detector, using a HP-5MS column $(30 \mathrm{~m} \times 0.25 \mathrm{~mm} \times 0.25 \mu \mathrm{m})$. The following temperature program was employed: $60^{\circ}(1 \mathrm{~min}) /$ $6^{\circ} / \mathrm{min} / 150^{\circ}(1 \mathrm{~min}) / 12^{\circ} / \mathrm{min} / 280^{\circ}(5 \mathrm{~min}) .{ }^{1} \mathrm{H}$ and ${ }^{13} \mathrm{C}$ NMR spectra were recorded on a Bruker AC-250 spectrometer $\left(250 \mathrm{MHz}{ }^{1} \mathrm{H}\right)$. The chemical shift scale was based on internal tetramethylsilane. Optical rotations were measured on a Dr.Kernchen Propol digital automatic polarimeter. Microanalyses were determined on a Analyzer 1106 Carlo Erba. TLC analyses were performed on Merck Kieselgel 60 $\mathrm{F}_{254}$ plates. All the chromatographic separations were carried out on silica gel columns.

Chiral HPLC analyses were performed on a Chiralcel OD column (Daicel-Japan) installed on a Merck-Hitachi L-6200 apparatus: $0.6 \mathrm{~mL} / \mathrm{min}$, UV detector (254 nm), hexane/isopropanol 95:5. The following retention times $\left(\mathrm{t}_{\mathrm{R}}\right)$ were observed: $\mathrm{t}_{\mathrm{R}}(2 R, 3 R)-\mathbf{4}=8.83 \mathrm{~min}, \mathrm{t}_{\mathrm{R}}(2 S, 3 R)-\mathbf{4}=9.67 \mathrm{~min}, \mathrm{t}_{\mathrm{R}}$ $(2 S, 3 S)-\mathbf{3}=13.15 \mathrm{~min}, \mathrm{t}_{\mathrm{R}}(2 S, 3 R)-\mathbf{3}=15.17 \mathrm{~min}, \mathrm{t}_{\mathrm{R}}(2 R, 3 R)-\mathbf{3}=15.53 \mathrm{~min}, \mathrm{t}_{\mathrm{R}}(2 R, 3 S)-\mathbf{3}=15.91 \mathrm{~min}$. Chiral GC analyses of Muguesia isomers and of alcohol $\mathbf{1 1}$ were performed on a Chirasil DEX CB, $25 \mathrm{~m} \times 0.25 \mathrm{~mm}$ (Chrompack) column, installed on a DANI HT 86.10 gas chromatograph). Muguesia isomers: temperature program $50^{\circ}\left(3^{\prime}\right)-2^{\circ} / \mathrm{min}-120^{\circ}-30^{\circ} / \mathrm{min}-180^{\circ} \mathrm{C}$; $t_{\mathrm{R}}$ acetate of $(2 S, 3 S)-\mathbf{1}=24.00$ $\min , \mathrm{t}_{\mathrm{R}}$ acetate of $(2 R, 3 R)-\mathbf{1}=26.09 \mathrm{~min}, \mathrm{t}_{\mathrm{R}}$ acetate of $(2 S, 3 R)-\mathbf{1}=24.23 \mathrm{~min}, \mathrm{t}_{\mathrm{R}}$ acetate of $(2 R, 3 S)-\mathbf{1}=$ 26.08 min. Compound 11: temperature program $50^{\circ}\left(3^{\prime}\right)-3.5^{\circ} / \mathrm{min}-180^{\circ} \mathrm{C} ; \mathrm{t}_{\mathrm{R}}(R)-11=21.1 \mathrm{~min}, \mathrm{t}_{\mathrm{R}}$ $(S)-11=21.4 \min$.

Compound $(S)$-10 was prepared according to ref.1. The derivative was submitted to Swern oxidation and conventional addition of methyl magnesium chloride in diethyl ether, to afford a 1:1 mixture (GC/MS see the experimental part) of $(2 S, 3 S)-\mathbf{1}$ and $(2 R, 3 S)$-1 (chiral GC of the corresponding acetate derivatives, see the experimental part). 
(2RS,3RS)- and (2RS,3SR)-3-Hydroxy-2-methyl-1-phenylbutan-1-one (3). Aldolic condensation of propiophenone $(40.0 \mathrm{~g}, 0.30 \mathrm{~mol})$ with acetaldehyde $(33 \mathrm{~g}, 0.74 \mathrm{~mol})$ gave compound 3 (27.9 $\mathrm{g}, 52$ $\%)$ as a 1:1 mixture of two racemic diastereoisomers $(2 R S, 3 R S)-3$ and $(2 R S, 3 S R)-3:{ }^{1} \mathrm{H} \mathrm{NMR}^{35}(250$ $\left.\mathrm{MHz}, \mathrm{CDCl}_{3}\right): \delta(\mathrm{ppm}) 7.98(\mathrm{~m}, 4 \mathrm{H}$, aromatic hydrogens of both diastereoisomers), $7.68(\mathrm{~m}, 2 \mathrm{H}$, aromatic hydrogens of both diastereoisomers), 7.41 (m, 4H, aromatic hydrogens of both diastereoisomers), 4.26 (qd, $1 \mathrm{H}, J=6.4,3.4 \mathrm{~Hz}, \mathrm{CH}-\mathrm{OH}$ of $(2 R S, 3 S R)-3$ ), 4.12 (quintet, $1 \mathrm{H}, J=6.4$ $\mathrm{Hz}, \mathrm{CH}-\mathrm{OH}$ of (2RS,3RS)-3), 3.48 (quintet, $1 \mathrm{H}, J=6.9 \mathrm{~Hz}, \mathrm{CH}-\mathrm{CH}_{3}$ of $\left.(2 R S, 3 R S)-3\right), 3.43$ (qd, $1 \mathrm{H}, J=$ 6.9, $3.4 \mathrm{~Hz}, \mathrm{CH}-\mathrm{CH}_{3}$ of (2RS,3SR)-3), $1.20-1.31$ (four overlapping d, $12 \mathrm{H}, \mathrm{CHCH}_{3}$ of both diastereoisomers); GC/MS (2RS,3SR)-3 $\mathrm{t}_{\mathrm{R}}=16.70 \mathrm{~min}, \mathrm{~m} / z(\%): 178\left(\mathrm{M}^{+}, 1\right), 160,(6), 133(31), 123$ (40), 105 (100), 77 (42); (2RS,3RS)-3 = $16.88 \mathrm{~min} \mathrm{m/z} \mathrm{( \% ):} 178\left(\mathrm{M}^{+}, 1\right), 160,(14), 133(39), 123(21)$, 105 (100), 77 (44). Anal. Calcd. for $\mathrm{C}_{11} \mathrm{H}_{14} \mathrm{O}_{2}$ : C, 74.13; H, 7.92. Found: C, 74.35; H, 7.78.

$(2 R, 3 R)-3-M e t h y l-4-p h e n y l-2-b u t a n o l ~((2 R, 3 R)-s y n-1)$. According to the same procedure described in the paper for $(2 S, 3 S)-\mathbf{1},(1 S, 2 S, 3 R)$-anti,syn-5 $(0.990 \mathrm{~g}, 5.50 \mathrm{mmol})$ gave $(2 R, 3 R)-1(0.69 \mathrm{~g}, 77 \%):$ de $=99 \%(\mathrm{GC} / \mathrm{MS}) ;$ ee $=99 \%($ chiral GC of the corresponding acetate derivative $) ;[\alpha]_{\mathrm{D}}=+8.1(c 0.92$, $\left.\mathrm{CHCl}_{3}\right) ;{ }^{1} \mathrm{H} \mathrm{NMR}$ and GC/MS data were in agreement with those of the enantiomer. Anal. Calcd. for $\mathrm{C}_{11} \mathrm{H}_{16} \mathrm{O}: \mathrm{C}, 80.44 ; \mathrm{H}, 9.82$. Found: C, 80.69; H, 9.74.

(2S,3R)-3-Methyl-4-phenyl-2-butanol ((2S,3R)-anti-1). According to the same procedure described in the paper for $(2 S, 3 S)-\mathbf{1},(1 R, 2 S, 3 S)-$ syn, anti-5 $(2.10 \mathrm{~g}, 0.012 \mathrm{~mol})$ gave $(2 S, 3 R)-1(1.38 \mathrm{~g}, 72 \%):$ de $=$ $99 \%(\mathrm{GC} / \mathrm{MS}) ;$ ee $=99 \%\left(\right.$ chiral $\mathrm{GC}$ of the corresponding acetate derivative); $[\alpha]_{\mathrm{D}}=+29.5(c 1.1$, $\left.\mathrm{CHCl}_{3}\right) ;{ }^{1} \mathrm{H} \mathrm{NMR}\left(250 \mathrm{MHz}, \mathrm{CDCl}_{3}\right) \delta(\mathrm{ppm}) 7.40-7.10(\mathrm{~m}, 5 \mathrm{H}$, aromatic hydrogens), 3.70 (quintet, $\left.1 \mathrm{H}, J=6.4 \mathrm{~Hz}, \mathrm{CH}_{3} \mathrm{CHOH}\right), 2.88(\mathrm{dd}, 1 \mathrm{H}, J=13.6,4.8 \mathrm{~Hz}, H-\mathrm{C}(4)), 2.34(\mathrm{dd}, 1 \mathrm{H}, J=13.6,9.6 \mathrm{~Hz}$, $H$-C(4)), $1.82(\mathrm{~m}, 1 \mathrm{H}, C H \mathrm{C}(3)), 1.21\left(\mathrm{~d}, 3 \mathrm{H}, J=6.4 \mathrm{~Hz}, C H_{3} \mathrm{CHOH}\right), 0.83(\mathrm{~d}, 3 \mathrm{H}, J=7.0 \mathrm{~Hz}$, 
$\left.\mathrm{CH}_{3} \mathrm{C}(3)\right) ;{ }^{13} \mathrm{C}$ NMR $\left(62.90 \mathrm{MHz}, \mathrm{CDCl}_{3}\right): \delta(\mathrm{ppm}) 140.9,128.9,128.1,125.4,71.0,42.17,38.8,19.7$, 14.6; GC/MS t $t_{\mathrm{R}}=14.10 \mathrm{~min}, \mathrm{~m} / z(\%) 164\left(\mathrm{M}^{+}, 14\right), 146(60), 131$ (87), 91 (100). Anal. Calcd. for $\mathrm{C}_{11} \mathrm{H}_{16} \mathrm{O}: \mathrm{C}, 80.44 ; \mathrm{H}, 9.82$. Found: C, 80.57; H, 9.98.

$(2 R, 3 S)$-2-Methyl-4-phenyl-2-butanol $((2 R, 3 S)$-anti-1). According to the same procedure described described in the paper for $(2 S, 3 S)-\mathbf{1},(1 R, 2 R, 3 R)$-anti,anti-5 $(3.10 \mathrm{~g}, 0.017 \mathrm{~mol})$ gave $(2 R, 3 S)-\mathbf{1}(1.92 \mathrm{~g}$, $68 \%): \mathrm{de}=99 \%(\mathrm{GC} / \mathrm{MS}) ;$ ee $=99 \%($ chiral GC of the corresponding acetate derivative $) ;[\alpha]_{\mathrm{D}}=-29.9$ (c 1.05, $\left.\mathrm{CHCl}_{3}\right) ;{ }^{1} \mathrm{H}$ NMR and GC/MS data were in agreement with those of the enantiomer. Anal. Calcd. for $\mathrm{C}_{11} \mathrm{H}_{16} \mathrm{O}: \mathrm{C}, 80.44 ; \mathrm{H}, 9.82$. Found: $\mathrm{C}, 80.16 ; \mathrm{H}, 10.07$.

(3R)-(-)-3-Methyl-4-phenyl-2-butanone ((R)-8). (+)-anti-1 (0.050 g, $0.304 \mathrm{mmol})$ was treated with Jones' reagent at $0^{\circ} \mathrm{C}$. The reaction mixture was filtered through a silica gel column (AcOEt), to afford $(R)-(-)-8(0.033 \mathrm{~g}, 68 \%):[\alpha]_{\mathrm{D}}=-29.9\left(c 1.05, \mathrm{CHCl}_{3}\right),[\alpha]_{\mathrm{D}}=-38.9(c 1.00, \mathrm{EtOH}) ;{ }^{1} \mathrm{H} \mathrm{NMR}$ and GC/MS data in accordance with those of the enantiomer. Anal. Calcd. for $\mathrm{C}_{11} \mathrm{H}_{14} \mathrm{O}: \mathrm{C}, 81.44 ; \mathrm{H}, 8.70$. Found: C, 81.13; H, 8.96 .

(S)-2-Phenylpropanol ((S)-11). Saponification of $(S)$-12 $(9.75 \mathrm{~g}, 0.055 \mathrm{~mol})$ with KOH $(3.68 \mathrm{~g}$, $0.066 \mathrm{~mol})$ in methanol $(100 \mathrm{~mL})$ gave $(S)-\mathbf{1 1}(6.80 \mathrm{~g}, 91 \%):$ ee $=92 \%(\operatorname{chiral~GC}),[\alpha]_{\mathrm{D}}=-13.9(c$ 1.22, $\left.\mathrm{CHCl}_{3}\right)$, lit. ${ }^{2}[\alpha]_{\mathrm{D}}=-16.09\left(c 0.513, \mathrm{CHCl}_{3}\right)$. The ${ }^{1} \mathrm{HNMR}$ spectrum was in accordance with that reported in literature. ${ }^{2}$

(R)-1-Bromo-2-phenylpropane $((\boldsymbol{R})-\mathbf{1 3})^{3}(R)-13(14.0 \mathrm{~g}, 80 \%)$ was prepared from (R)-11 (12.1 g, $0.088 \mathrm{mmol})$ according to the procedure reported in ref.3: $[\alpha]_{\mathrm{D}}=+17.5(c 0.95, \mathrm{EtOH})$, lit. $^{4}[\alpha]_{\mathrm{D}}=-$ 18.1 (c 1, EtOH) for the (S)-enantiomer; ${ }^{1} \mathrm{H}$ NMR was in accordance with that described in literature. ${ }^{3}$ 
(S)-1-Bromo-2-phenylpropane $((S)-13) .(S)-13(8.29 \mathrm{~g}, 85 \%)$ was obtained from $(S)-11(6.70 \mathrm{~g}$, $0.049 \mathrm{~mol})$ according according to the procedure reported in ref.3: $[\alpha]_{\mathrm{D}}=-17.8(c 0.78, \mathrm{EtOH})$, lit. ${ }^{4}[\alpha]_{\mathrm{D}}=-18.1(c 1, \mathrm{EtOH})$.

(2RS,4R)-2-Methyl-4-phenylpentanoic acid $((\mathbf{2} R S, 4 R)-14) .(2 R S, 4 R)-14(4.60 \mathrm{~g}, 59 \%)$ was prepared from $(S)-\mathbf{1 3}(8.10 \mathrm{~g}, 0.040 \mathrm{~mol})$ according to the same procedure used to prepare $(2 R S, 4 S)-14$ from $(R)$-13. ${ }^{1} \mathrm{H}$ NMR and GC/MS data were in accordance with those of $(2 R S, 4 S)-14$. Anal. Calcd for $\mathrm{C}_{12} \mathrm{H}_{16} \mathrm{O}_{2}$ : C 74.97, $\mathrm{H}$ 8.39; found C, 75.11; H, 8.13.

(2RS,4S)-2-Methyl-4-phenylpentanol ((2RS,4S)-2). (2RS,4S)-14 (7.50 g, $0.039 \mathrm{~mol})$ was reduced with $\mathrm{LiAlH}_{4}(1.48 \mathrm{~g}, 0.039 \mathrm{~mol})$ in refluxing THF $(100 \mathrm{~mL})$. After the usual work up, $(2 R S, 4 S)-2(5.62$ g, 81\%) was obtained.

(2RS,4R)-2-Methyl-4-phenylpentanol ((2RS,4R)-2). (2RS,4R)-14 (4.50 g, $0.023 \mathrm{~mol})$ was reduced with $\mathrm{LiAlH}_{4}(0.874 \mathrm{~g}, 0.023 \mathrm{~mol})$ in refluxing THF $(\mathrm{ml})$. After the usual work up, $(2 R S, 4 R)-2(3.21 \mathrm{~g}$, $77 \%$ ) was obtained.

$(2 S, 4 R)-2-M e t h y l-4-p h e n y l p e n t a n o l \quad((2 S, 4 R)-2)$ and $(2 R, 4 R)$ - Acetic acid 2-Methyl-4phenylpent-1-yl ester $((\mathbf{2} \boldsymbol{R}, \mathbf{4 R})-\mathbf{1 5}) .(2 R S, 4 R)-2(3.10 \mathrm{~g}, 0.017 \mathrm{~mol})$ was treated with PPL $(3 \mathrm{~g})$ in $t$ butylmethyl ether solution $(30 \mathrm{~mL})$ in the presence of vinyl acetate $(5 \mathrm{~mL})$ for $1 \mathrm{~h}$. The reaction mixture was filtered and concentrated under reduced pressure. The residue was chromatographed on a silica gel column, to give $(2 R, 4 R)-15(0.449 \mathrm{~g}, 12 \%):[\alpha]_{\mathrm{D}}=+4.12\left(c 0.97, \mathrm{CHCl}_{3}\right)$, ee $=92 \%($ from $(S)-11)$, de $=85 \%\left({ }^{1} \mathrm{H} \mathrm{NMR} \delta \mathrm{CH}_{3} \mathrm{COO}\right) ;{ }^{1} \mathrm{H} \mathrm{NMR}\left(250 \mathrm{MHz}, \mathrm{CDCl}_{3}\right) \delta(\mathrm{ppm}) 7.30-7.05(\mathrm{~m}, 5 \mathrm{H}$, aromatic 
hydrogens), $3.91\left(\mathrm{~m}, 2 \mathrm{H}, \mathrm{CH}_{2}-\mathrm{OAc}\right), 2.80(\mathrm{~m}, 1 \mathrm{H}, \mathrm{CHPh}), 2.06\left(\mathrm{~s}, 3 \mathrm{H}, \mathrm{CH}_{3} \mathrm{COO}\right), 1.80-1.30(\mathrm{~m}, 3 \mathrm{H}$, $H-\mathrm{C}(2)+2 H-\mathrm{C}(3)), 1.23\left(\mathrm{~d}, 3 \mathrm{H}, J=6.5 \mathrm{~Hz}, \mathrm{CH}_{3}-\mathrm{C}(4)\right), 0.90\left(\mathrm{~d}, 3 \mathrm{H}, J=6.9 \mathrm{~Hz}, \mathrm{CH}_{3}-\mathrm{C}(2)\right)$. Anal.Calcd. for $\mathrm{C}_{14} \mathrm{H}_{20} \mathrm{O}_{2}:$ C, 76.33; H, 9.15; found: C, 76.01; H, 8.98.

The unreacted alcohol was submitted to prolonged PPL treatment to afford $(2 S, 4 R)-2:[\alpha]_{\mathrm{D}}=+25.5$ $\left(c 1.0, \mathrm{CHCl}_{3}\right)$, ee $=92 \%($ from $(S)-11), \mathrm{de}=87 \%\left({ }^{1} \mathrm{H}\right.$ NMR of the corresponding acetate, $\left.\delta \mathrm{CH}_{3} \mathrm{COO}\right)$. ${ }^{1} \mathrm{H}$ NMR (250 MHz, $\left.\mathrm{CDCl}_{3}\right) \delta(\mathrm{ppm}) 7.33-7.12$ (m, 5H, aromatic hydrogens), 3.41 (dd, $1 \mathrm{H}, J=10.4$, $5.5 \mathrm{~Hz}, \mathrm{CH}-\mathrm{OH}), 3.34(\mathrm{dd}, 1 \mathrm{H}, J(\mathrm{H}, \mathrm{H})=10.4,6.1 \mathrm{~Hz}, \mathrm{CH}-\mathrm{OH}), 2.83(\mathrm{~m}, 1 \mathrm{H} ; \mathrm{CHPh}), 1.76(\mathrm{~m}, 1 \mathrm{H})$, $1.40(2 \mathrm{H}, \mathrm{m}), 1.24\left(\mathrm{~d}, 3 \mathrm{H}, J=6.5 \mathrm{~Hz}, \mathrm{CH}_{3} \mathrm{-C}(4)\right), 0.91\left(\mathrm{~d}, 3 \mathrm{H}, J=6.1 \mathrm{~Hz}, \mathrm{CH}_{3}-\mathrm{C}(2)\right) ;{ }^{13} \mathrm{C} \mathrm{NMR}(62.90$ $\left.\mathrm{MHz}, \mathrm{CDCl}_{3}\right): \delta(\mathrm{ppm}) 147.1,128.4,126.9,125.9,68.6,41.6,37.3,33.6,23.7,16.2$. Anal. Calcd. for $\mathrm{C}_{12} \mathrm{H}_{18} \mathrm{O}: \mathrm{C}, 80.85$; H 10.18; found: C, 80.72; H 10.35 .

$\mathbf{( 2 R , 4 R ) - 2 - M e t h y l - 4 - p h e n y l p e n t a n o l ~}((\mathbf{2} R, 4 R)-2)$. Saponification of $(2 R, 4 R)-15(0.400 \mathrm{~g}, 1.82$ mmol) with $\mathrm{KOH}(0.121 \mathrm{~g}, 2.17 \mathrm{mmol})$ in methanol $(10 \mathrm{~mL})$ gave after the usual work-up $(2 R, 4 R)-2$ $(0.252 \mathrm{~g}, 78 \%):[\alpha]_{\mathrm{D}}=-12.6\left(c 0.87, \mathrm{CHCl}_{3}\right)$, ee $=92 \%($ from $(S)-11), \mathrm{de}=85 \%\left({ }^{1} \mathrm{H} \mathrm{NMR} \delta \mathrm{CH}_{3} \mathrm{COO}\right.$ of the corresponding acetate). NMR data were in agreement with those of the enantiomer. Anal. Calcd. for $\mathrm{C}_{12} \mathrm{H}_{18} \mathrm{O}: \mathrm{C}, 80.85 ; \mathrm{H} 10.18$; found: $\mathrm{C}, 80.68 ; \mathrm{H} 10.39$.

$(2 R, 4 R)$-2-Methyl-4-phenylpentanoic acid methyl ester $((2 R, 4 R)$-anti-16). A sample of the alcohol, obtained by hydrolysis of the acetate recovered from the PPL transesterification of $(2 R S, 4 R)-\mathbf{2}$, was treated with Jones' reagent and then with diazomethane in diethyl ether. The methyl ester obtained resulted to be $(2 R, 4 R)-16$ by comparison of its ${ }^{1} \mathrm{H}$ NMR spectrum with the one described for the racemic anti diastereoisomer in literature ${ }^{5}:{ }^{1} \mathrm{H}$ NMR $\left(250 \mathrm{MHz}, \mathrm{CDCl}_{3}\right) \delta(\mathrm{ppm}) 7.42-7.10(\mathrm{~m}, 5 \mathrm{H}$, aromatic hydrogens), $3.66(\mathrm{~s}, 3 \mathrm{H}, \mathrm{COOMe}), 2.70(\mathrm{~m}, 1 \mathrm{H}, H-\mathrm{C}(4)), 2.29(\mathrm{~m}, 1 \mathrm{H}, H-\mathrm{C}(2)), 2.00(\mathrm{~m}, 1 \mathrm{H}$, 
$H-\mathrm{C}(3)), 1.62(\mathrm{~m}, 1 \mathrm{H}, H-\mathrm{C}(3)), 1.23\left(\mathrm{~d}, 3 \mathrm{H}, J=7.0 \mathrm{~Hz}, \mathrm{CH}_{3}-\mathrm{C}(4)\right), 1.08\left(\mathrm{~d}, 3 \mathrm{H}, J=6.1 \mathrm{~Hz}, \mathrm{CH}_{3^{-}}\right.$ $\mathrm{C}(2)) ; \mathrm{GC} / \mathrm{MS} \mathrm{t}_{\mathrm{R}}=16.04 \mathrm{~min} \mathrm{~m} / z(\%): 206\left(\mathrm{M}^{+}, 6\right), 175(12), 119(94), 105(88), 88(100)$.

X-ray Crystallographic study. ${ }^{\#}$ Compound $(1 R, 2 S, 3 S)$-syn-anti-5 : $\mathrm{C}_{11} \mathrm{H}_{16} \mathrm{O}_{2}, \quad \mathrm{M}_{\mathrm{r}}=180.24$, orthorhombic, space group P2(1)2(1)2(1), a =6.211(2), $b=9.483(2), c=17.825(3) \AA, V=1049(4) \AA^{3}$, $\mathrm{Z}=4, \mathrm{D}_{\mathrm{c}}=1.140 \mathrm{~g} \mathrm{~cm}^{-3}, \mu=0.612 \mathrm{~mm}^{-1}, \mathrm{~F}(000)=392 ; \lambda=1.54179 \AA$, room temperature, colourless crystal $(0.5 \times 0.2 \times 0.04 \mathrm{~mm})$. The compound crystallises in the form of a bundle of needles and it was not possible to select a single crystal of good size and quality. Intensitiy data was collected using a Siemens $\mathrm{P} 4$ diffractometer with graphite monochromated $\mathrm{Cu}-\mathrm{K} \alpha$ radiation $\left(\lambda=1.54179 \mathrm{~A}^{\circ}\right)$, using $\theta / 2 \theta$ scan technique. Unit cell parameters were determined using 58 reflections in the range $17.3 \leq 2 \theta \leq$ $50.4^{\circ}$; a total of 1436 reflections ( 1285 unique, $\mathrm{R}_{\text {int }}=0.0907$ ) were collected up to $130^{\circ}$ in $2 \theta$ and index range: $\quad-1 \leq \mathrm{h} \leq 7,-11 \leq \mathrm{k} \leq 1,-1 \leq 1 \leq 20$. No decay correction was deemed necessary.

The structure was solved by direct methods using SIR $97^{6}$ program which revealed the position of all non $\mathrm{H}$-atoms. Aromatic and methyl $\mathrm{H}$-atoms were fixed geometrically and allowed to ride on their parent atoms, the other $\mathrm{H}$-atoms were freely refined. The refinement was carried out on $\mathrm{F}^{2}$ by fullmatrix least-squares procedure with SHELXL97 $7^{7}$ for 124 parameters, with anisotropic temperature factors for non-H atoms. The low quality of the crystal affected the final refinement, due to the weak intensities of the high-angle data. The final stage converged to $R=0.0623\left(R_{w}=0.153\right.$ for 898 observed reflections, with $I \geq 2 \sigma(I)$, and $R=0.0964\left(R_{w}=0.1769\right)$ for all unique reflections. Mean shift/error $<0.001$; the goodness of fit, $\mathrm{S},=1.040$. The final difference map showed a maximum and minimum residual peaks of 0.22 and $-0.21 \mathrm{e} \AA^{-3}$, respectively.

\# Supplementary crystallographic data for the structures reported in this paper in the form of CIF files has been deposited with the Cambridge Crystallographic Data Centre with the following deposition numbers: CCDC 245674 for (1R,2S,3S)-5 and CCDC 245675 for $(1 R, 2 R, 3 R)-5$. 
In the crystal packing, the molecules are stacked in columns of double chains parallel to $a$ axis: each molecule is linked by intermolecular hydrogen bonds to one molecule above and one molecule below in the same chain and by two hydrogen bonds to the adjacent molecules of the other chain. In this way, each of the two oxygen atoms acts both as donor and as acceptor of hydrogen bonds.

Compound $(1 R, 2 R, 3 R)$-anti,anti-5: $\mathrm{C}_{11} \mathrm{H}_{16} \mathrm{O}_{2}, \mathrm{M}_{\mathrm{r}}=180.24$, monoclinic, space group $\mathrm{P} 2(1), \mathrm{a}=$ $6.435, \mathrm{~b}=6.853, \mathrm{c}=12.112 \AA, \alpha=90, \beta=103.750, \gamma=90^{\circ}, \mathrm{V}=518.8 \AA^{3}, \mathrm{Z}=2, \mathrm{D}_{\mathrm{c}}=1.154 \mathrm{~g} \mathrm{~cm}^{-3}$, $\mu=0.620 \mathrm{~mm}^{-1}, \mathrm{~F}(000)=196 ; \lambda=1.54179 \AA$, room temperature, colourless, crystal $(0.2 \times 0.2 \times 0.7$ $\mathrm{mm})$. Intensities data were collected on a Siemens P4 diffractometer with graphite monochromated Cu$\mathrm{K} \alpha$ radiation $\left(\lambda=1.54179 \mathrm{~A}^{\circ}\right)$, using $\theta / 2 \theta$ scan technique. Unit cell parameters were determined using 78 reflections in the range $7.6 \leq 2 \theta \leq 80.2^{\circ}$; a total of 1946 reflections (1657 unique, $R_{\text {int }}=0.0208$ ) were collected up to $136^{\circ}$ in $2 \theta$ and index range:- $-7 \leq \mathrm{h} \leq 7,-7 \leq \mathrm{k} \leq 8,-14 \leq 1 \leq 14$. An intensity decay of $6 \%$ was observed during data collection and a linear decay correction was applied during data redaction..$^{8}$

The structure was solved by direct methods using SIR9 $97^{6}$ program which revealed the position of all non $\mathrm{H}$-atoms; aromatic and methyl $\mathrm{H}$-atoms were fixed geometrically and allowed to ride on their parent atoms, the other $\mathrm{H}$-atoms were freely refined. The refinement was carried out on $\mathrm{F}^{2}$ by fullmatrix least-squares procedure with SHELXL97 ${ }^{7}$ for 131 parameters, with anisotropic temperature factors for non-H atoms. The final stage converged to $R=0.0400\left(R_{w}=0.1170\right)$ for 1442 observed reflections, with $I \geq 2 \sigma(I)$, and $R=0.0473\left(R_{w}=0.1234\right)$ for all unique reflections. The mean shift/error was 0.002 and the goodness of fit, S, was 1.066. The final difference map showed a maximum and minimum residual peaks of 0.110 and $-0.102 \mathrm{e}^{-3}$, respectively.

The crystal packing of this compound is very similar to that of $(1 R, 2 S, 3 S)$-syn-anti-5: each of the two oxygen atoms acts both as donor and as acceptor of hydrogen bonds, forming double chains parallel to $b$ axis. 


\section{References}

1) Fuganti. C.; Grasselli P. Chem. Ind. (London) 1977, 983.

2) Toda, A.; Aoyama, H.; Mimura, N.; Ohno, H.; Fujii, N.; Ibuka, T. J.Org.Chem, 1998, 63, 7053 7061

3) Prins, L. J.; Hulst, R.; Timmerman, P.; Reinhoudt, D. N. Chem.Eur.J, 2002, 8, 2288.

4) Jones, D. M.; Nilsson, B.; Szelke, M., J.Org.Chem. 1993, 58, 2286.

5) Barbero, A.; Blakemore, D. C.; Fleming, I.; Wesley, R. N. J.Chem.Soc. Perkin Trans.1, 1997, 1329.

6) Altomare, A.; Burla, M.C.; Camalli, M.; Cascarano, G.L.; Giacovazzo, C.; Guagliardi, A.; Moliterni, A.G.G.; Polidori, G.P.; Spagna, R. SIR97: A New Tool for Crystal Structure Determination and Refinement. J. Appl. Cryst. 1999, 32, 115-119.

7) Sheldrick. G.M. SHELXL-97. Program for the Refinement of Crystal Structures. 1997. University of Göttingen, Germany

8) Siemens. XSCANS. Siemens Analytical X-ray Instruments Inc. Madison, Wisconsin, USA. 